\title{
PENGARUH UKURAN PERUSAHAAN, RISIKO OPERASI, DAN PROFITABILITAS TERHADAP PRAKTIK PERATAAN LABA PADA PERUSAHAAN MANUFAKTUR DI BEI 2015-2017
}

\author{
Dian Purwandari, S.E., M.Ak. ${ }^{1}$ \\ 1 Universitas Buana Perjuangan Karawang \\ ${ }^{1}$ dian.purwandari@ubpkarawang.ac.id
}

Penelitian ini membahas tentang pengaruh ukuran perusahaan, risiko perusahaan, dan profitabilitas terhadap praktik perataan laba (income smoothing) pada perusahaan manufaktur yang terdaftar di Bursa Efek Indonesia periode 2015-2017. Penelitian ini bertujuan untuk mengetahui dan menganalisis pengaruh ukuran perusahaan, risiko perusahaan, dan profitabilitas secara parsial dan simultan terhadap praktik perataan laba (income smoothing) pada perusahaan manufaktur yang terdaftar di Bursa Efek Indonesia periode 2015-2017. Penelitian ini menggunakan 31 sampel dari jumlah populasi 154 perusahaan manufaktur yang terdaftar pada Bursa Efek Indonesia (BEI). Pengambilan sampel dilakukan dengan cara purposive sampling. Hasil penelitian diperoleh bahwa profitabilitas memiliki pengaruh terhadap praktik perataan laba (income smoothing) dan ukuran perusahaan, risiko perusahaan, dan profitabilitas secara simultan memiliki pengaruh terhadap praktik perataan laba (income smoothing), dengan pengaruh profitabilitas yaitu sebesar $24,50 \%$ dan hasil pengujian secara simultan sebesar 25,60\%, sedangkan variabel lain yaitu ukuran perusahaan dan risiko perusahaan tidak mempunyai pengaruh terhadap jumlah dividen tunai.

\section{Pendahuluan}

Ketatnya persaingan dalam dunia usaha atau bisnis menjadi pemicu yang kuat bagi manajemen perusahaan untuk menampilkan performa terbaik bagi perusahaan yang dipimpinnya, karena baik buruknya performa perusahaan akan berdampak terhadap nilai pasar perusahaan dan mempengaruhi minat investor untuk menanam atau menarik investasinya dari sebuah perusahaan. Hal ini mempengaruhi ketersediaan dan besarnya dana yang bisa dimanfaatkan perusahaan, serta tinggi rendahnya Cost Of Capital (COC) yang harus

\section{4 | Jurnal Buana Akuntansi}




\section{Buana Akuntansi}

ditanggungnya. Selain itu, manajemen juga bertanggung jawab untuk menyediakan laporan keuangan kepada semua pihak yang berkepentingan. Berdasarkan laporan keuangan tersebut, investor dan kreditor dapat mengambil keputusan-keputusan ekonomi dengan mengetahui informasi laba suatu perusahaan.

Informasi laba memiliki pengaruh yang sangat besar bagi para penggunanya dalam mengambil suatu keputusan, sehingga perhatian investor sering terpusat pada informasi laba perusahaan. Praktik perataan laba meliputi usaha untuk memperkecil jumlah laba yang dilaporkan jika laba aktual lebih besar dari laba normal, dan untuk memperbesar laba yang dilaporkan jika laba lebih kecil dari laba normal (Prasetio dan Wiryawan, 2002:46). Menurut Jatiningrum (2000), faktor-faktor yang mempengaruhi praktik perataan laba pada perusahaan go-public yang terdaftar di Bursa Efek Jakarta antara lain, ukuran perusahaan, profitabilitas, dan sektor industri.

Ukuran perusahaan umumnya dinilai dari besarnya aktiva perusahaan. Perusahaan besar memiliki kemungkinan yang lebih besar melakukan perataan laba dibandingkan dengan perusahaan kecil, karena semakin besar perusahaan, maka semakin besar biaya yang dibebankan pemerintah, karena hal tersebut dianggap sesuai dengan kemampuan perusahaan. Profitabilitas merupakan kemampuan perusahaan dalam memperoleh laba. Perusahaan sering menggunakan rasio profitabilitas sebagai tolak ukur dalam melakukan perataan laba. Menurut Jatiningrum (2000), profitabilitas perusahaan mempunyai pengaruh yang signifikan terhadap perataan laba. Perusahaan dengan profitabilitas positif tidak menunjukkan indikasi melakukan praktik perataan laba, sebaliknya perusahaan dengan profitabilitas rendah diindikasikan melakukan praktik perataan laba. Berdasarkan latar belakang yang telah diuraikan diatas, maka rumusan masalah dalam penelitian ini adalah:

1. Apakah terdapat pengaruh antara ukuran perusahaan terhadap praktik perataan laba pada perusahaan manufaktur yang terdaftar di BEl?

2. Apakah terdapat pengaruh antara risiko operasi terhadap praktik perataan laba pada perusahaan manufaktur yang terdaftar di BEI?

3. Apakah terdapat pengaruh antara profitabilitas terhadap praktik perataan laba pada perusahaan manufaktur yang terdaftar di BEI?

4. Apakah terdapat pengaruh antara ukuran perusahaan, risiko perusahaan, dan profitabilitas terhadap praktik perataan laba pada perusahaan manufaktur yang terdaftar di BEI? 


\section{Buana Akuntansi}

\section{Tinjauan Pustaka}

\subsection{Ukuran Perusahaan}

Wahidatul Husnaini dan Rosyida (2006) yang menyimpulkan bahwa perusahaan perata laba memiliki ukuran yang besar daripada perusahaan bukan perata laba. Ukuran perusahaan dihitung dengan menggunakan rumus:

$$
\text { Ukuran Perusahaan }=\text { Log Total Aktiva }
$$

\subsection{Risiko Perusahaan}

Dalam penelitian ini, risiko perusahaan diwakili oleh Debt to Equity Ratio (DER). Debt to Equity Ratio (DER) mencerminkan kemampuan perusahaan dalam memenuhi seluruh kewajibannya yang ditunjukkan oleh berapa bagian modal sendiri yang digunakan untuk membayar hutang. Menurut Ni Luh dan Gerianta (2008) ditinjau dari financial leverage, perusahaan dengan tingkat hutang yang tinggi cenderung untuk melakukan pengelolaan laba untuk menghindari pelanggaran perjanjian hutang. DER dapat dihitung dengan menggunakan rumus sebagai berikut:

$$
\text { Debt to Equity Ratio }=\frac{\text { Total Liabilitas }}{\text { Total Ekuitas }}
$$

\subsection{Profitabilitas}

Menurut Dermawan (2008), profitabilitas adalah hasil bersih dari serangkaian kebijakan dan keputusan. Rasio profitabilitas menunjukkan pengaruh gabungan dari likuiditas, manajemen aktiva, dan hutang terhadap hasil operasi. Penelitian ini menggunakan Return on Total Assets (ROA) sebagai ukuran profitabilitas. Return on Total Assets dapat dihitung dengan menggunakan rumus:

$$
\text { Return on Total Assets }=\frac{\text { Earnings After Tax }}{\text { Total Assets }}
$$

\subsection{Perataan Laba}

Menurut Beidlman yang dikutip Belkaoui (2007) perataan laba (Income Smoothing) adalah pengurangan atau fluktuasi yang disengaja terhadap beberapa tingkatan laba yang saat ini dianggap normal oleh perusahaan. Perataan laba dapat dihitung dengan menggunakan indeks eckel untuk membedakan antara perusahaan perata laba degan perusahaan bukan perata laba, dengan menggunakan rumus:

$$
\text { Indeks Eckel }: \frac{C V_{\Delta I}}{C V_{\Delta S}}
$$

\section{6 | Jurnal Buana Akuntansi}




\section{Buana Akuntansi}

\subsection{Penelitian Terdahulu}

Beberapa penelitian telah mencoba untuk mengidentifikasikan dan menguji faktor-faktor yang mendorong manajemen melakukan perataan laba, namun masih menunjukkan signifikansi hasil yang berbeda pada setiap penelitian. Antara lain penelitian yang dilakukan oleh Antariksa dan Eka (2005) mengenai "Faktor-Faktor yang Mempengaruhi Praktik Perataan Laba pada Perusahaan-Perusahaan di Bursa Efek Jakarta (BEJ) pada Periode 2000-2002". Variabel yang digunakan, sebagai variabel independen adalah ukuran perusahaan, risiko perusahaan, profitabilitas, dan operating leverage, serta variabel dependen yaitu perataan laba. Hasil penelitiannya secara umum adalah risiko perusahaan memiliki pegaruh positif yang signifikan terhadap praktik perataan laba, profitabilitas mempunyai pengaruh negatif yang signifikan terhadap praktik perataan laba, sedangkan ukuran perusahaan dan operating leverage tidak memiliki pengaruh yang signifikan terhadap perataan laba.

Fongwati Budhijono (2006), melakukan penelitian tentang "Evaluasi Perataan Laba pada Industri Manufaktur dan Lembaga Keuangan yang Terdaftar di Bursa Efek Jakarta (BEJ) pada Periode 2000-2004". Variabel yang digunakan, sebagai variabel independen adalah ukuran perusahaan, profitabilitas, kategori kelompok usaha, operating leverage, dan winner/losser stock, dan variabel dependen adalah perataan laba (income smoothing). Hasil dari penelitian yang dilakukan adalah ukuran perusahaan, profitabilitas, dan perusahaan yang berstatus winner stock memiliki pengaruh yang signifikan terhadap perataan laba, sedangkan operating leverage memiliki pengaruh negatif signifikan terhadap perataan laba.

Etty dan Tobia (2006), melakukan penelitian "Pengaruh faktor-faktor internal perusahaan terhadap income smoothing" periode 2002-2004. Variabel yang digunakan, sebagai variabel independen adalah besaran perusahaan, profitabilitas, leverage operasi, dan sektor industri, serta variabel dependen adalah perataan laba (income smoothing). Hasil penelitiannya adalah sektor industri dan profitabilitas memiliki pengaruh yang signifikan terhadap perataan laba sedangkan variabel lainnya kurang berpengaruh secara signifikan.

Muhammad Yusuf dan Soraya (2004), melakukan penelitian tentang "Faktor-Faktor yang Mempengaruhi Praktik Perataan Laba pada Perusahaan Asing dan Non-Asing di Indonesia periode 1998-2001". Variabel yang digunakan sebagai variabel independen yaitu ukuran perusahaan, profitabilitas, operating leverage, dan status perusahaan, sedangkan variabel dependen yaitu praktik perataan laba. Hasil yang diperoleh dalam penelitian ini adalah operating leverage memiliki pengaruh terhadap praktik perataan laba sedangkan

\section{7 | Jurnal Buana Akuntansi}




\section{Buana Akuntansi}

profitabilitas, ukuran perusahaan, dan status perusahaan tidak memiliki pengaruh terhadap praktik perataan laba.

Wahidatul Husnaini dan Rosyida (2006), melakukan penelitian tentang "Analisis FaktorFaktor yang Mempengaruhi Income Smoothing pada Perusahaan Manufaktur yang Terdaftar di BEJ Periode 2003-2005”. Variabel independennya adalah pendanaan hutang, profitabilitas, ukuran perusahaan, besaran perusahaan dan net profit margin, sedangkan variabel dependen adalah income smoothing. Hasil yang diperoleh yaitu hanya variabel pendanaan hutang yang memiliki pengaruh terhadap income smoothing sedangkan variabel lainnya tidak memiliki pengaruh terhadap income smoothing.

\subsection{Kerangka Pemikiran}

\subsubsection{Pengaruh Ukuran Perusahaan terhadap Praktik Perataan Laba}

Ukuran perusahaan (firm size) dapat dinyatakan dalam total aktiva, penjualan, dan kapitalisasi pasar. Semakin besar total aktiva, penjualan, dan kapitalisasi pasar maka semakin besar pula ukuran perusahaan itu. Total aktiva digunakan sebagai ukuran besarnya suatu perusahaan karena aktiva dianggap memiliki nilai yang paling stabil. Semakin besar suatu perusahaan maka kemungkinan untuk melakukan perataan laba juga semakin besar. Hal tersebut didukung oleh penelitian yang dilakukan oleh Fongwati (2006), yang menyatakan bahwa ukuran perusahaan memiliki pengaruh yang positif terhadap praktik perataan laba. Berdasarkan uraian diatas, maka dapat dirumuskan hipotesis sebagai berikut:

$\mathrm{Ho}_{1}$ : Tidak terdapat pengaruh antara ukuran perusahaan terhadap praktik perataan laba pada perusahaan manufaktur yang terdaftar di Bursa Efek Indonesia (BEI).

$\mathrm{Ha}_{1}$ : Terdapat pengaruh antara ukuran perusahaan terhadap praktik perataan laba pada perusahaan manufaktur yang terdaftar di Bursa Efek Indonesia (BEI).

\subsubsection{Pengaruh Risiko Perusahaan terhadap Praktik Perataan Laba}

Risiko dinyatakan sebagai seberapa jauh hasil yang diperoleh dapat menyimpang dari yang diharapkan, oleh karena itu digunakan ukuran tertentu untuk mengetahui tingkat risiko yang dimiliki. Dalam penelitian ini risiko perusahaan diwakili oleh Debt to Equity Ratio (DER). DER digunakan untuk menghitung sejauh mana perusahaan dibiayai oleh hutang, dengan tingkat DER yang tinggi maka akan mempengaruhi keuntungan yang diperoleh perusahaan. Variabel ini mempengaruhi perataan laba (income smoothing) karena keinginan para kreditur untuk mengamankan dana yang disetor di perusahaan agar tetap stabil dan tidak berfluktuasi. Hal tersebut didukung oleh penelitian yang dilakukan Antariksa

\section{8 | Jurnal Buana Akuntansi}




\section{Buana Akuntansi}

dan Eka (2005) dan Dhamar (2010) yang menyatakan bahwa risiko perusahaan memiliki pengaruh yang positif terhadap perataan laba. Berdasarkan uraian tersebut, dapat dirumuskan hipotesis sebagai berikut:

$\mathrm{Ho}_{2}$ : Tidak terdapat pengaruh antara risiko perusahaan terhadap praktik perataan laba pada perusahaan manufaktur yang terdaftar di Bursa Efek Indonesia (BEI).

$\mathrm{Ha}_{2}$ : Terdapat pengaruh antara risiko perusahaan terhadap praktik perataan laba pada perusahaan manufaktur yang terdaftar di Bursa Efek Indonesia (BEI).

\subsubsection{Pengaruh Profitabilitas terhadap Praktik Perataan Laba}

Profitabilitas merupakan ukuran penting yang menilai sehat atau tidaknya perusahaan, yang mempengaruhi investor dalam mengambil keputusan. Perusahaan dengan tingkat profitabilitas yang stabil akan memberikan keyakinan kepada investor bahwa perusahaan tersebut memiliki kinerja yang baik dalam menghasilkan laba. Profitabilitas dikatakan mempengaruhi income smoothing, karena profitabilitas yang cenderung turun, akan mempengaruhi persepsi dan kredibilitas akan performance dari perusahaan, oleh karena itu manajemen cenderung melakukan perataan laba. Penelitian tentang profitabilitas ini didukung oleh penelitian yang dilakukan oleh Etty dan Tobia (2006), profitabilitas memiliki pengaruh yang signifikan terhadap praktik perataan laba. Berdasarkan uraian tersebut maka dapat dirumuskan hipotesis sebagai berikut:

$\mathrm{Ho}_{3}$ : Tidak terdapat pengaruh antara profitabilitas terhadap praktik perataan laba pada perusahaan manufaktur yang terdaftar di Bursa Efek Indonesia (BEI).

$\mathrm{Ha}_{3}$ : Terdapat pengaruh antara profitabilitas terhadap praktik perataan laba pada perusahaan manufaktur yang terdaftar di Bursa Efek Indonesia (BEI).

\subsubsection{Pengaruh Ukuran Perusahaan, Risiko Perusahaan dan Profitabilitas terhadap Praktik Perataan Laba}

Ukuran perusahaan umumnya dinilai dari besarnya aktiva perusahaan. Karena aktiva cenderung memiliki nilai yang relatif lebih stabil. Risiko perusahaan dalam penelitian ini diwakili oleh Debt to Equity Ratio (DER), karena DER mencerminkan kemampuan perusahaan dalam memenuhi seluruh kewajibannya, semakin rendah rasio ini maka semakin tinggi kemampuan perusahaan membayar seluruh kewajiban. Profitabilitas yang diwakili oleh ROA menunjukkan, kemampuan perusahaan dalam menghasilkan laba melalui penggunaan aktiva, semakin tinggi rasio ini maka semakin baik produktifitas asset dalam menghasilkan keuntungan bersih. 


\section{Buana Akuntansi}

Berdasarkan teori diatas, dapat disimpulkan bahwa semakin besar ukuran perusahaan maka profitabilitas dan risiko yang diperoleh perusahaan tersebut semakin besar sehingga memiliki kemungkinan yang besar untuk melakukan praktik perataan laba. Berdasarkan uraian tersebut, maka dapat dirumuskan hipotesis sebagai berikut:

$\mathrm{Ho}_{4}$ : Tidak terdapat pengaruh antara ukuran perusahaan, risiko perusahaan, dan profitabilitas terhadap praktik perataan laba pada perusahaan manufaktur yang terdaftar di Bursa Efek Indonesia (BEI).

$\mathrm{Ha}_{4}$ : Terdapat pengaruh antara ukuran perusahaan, risiko perusahaan, dan profitabilitas terhadap praktik perataan laba pada perusahaan manufaktur yang terdaftar di Bursa Efek Indonesia (BEI).

\section{Gambar 2.1 Kerangka Pemikiran}

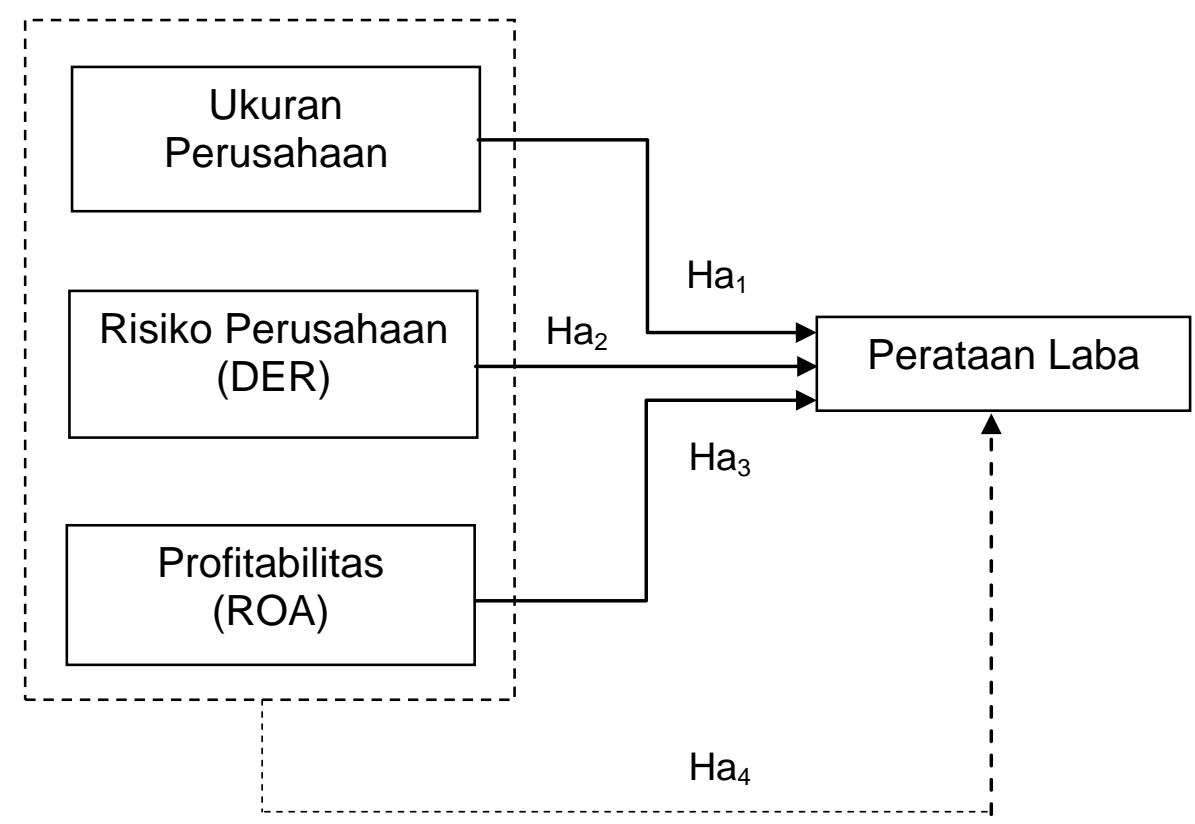

\section{Metodologi Penelitian}

Berdasarkan tingkat eksplanasinya, jenis penelitian yang digunakan dalam penelitian ini adalah penelitian asosiatif. Menurut Sugiyono (2007), penelitian asosiatif adalah penelitian yang bertujuan untuk mengetahui hubungan sebab akibat antara variabel bebas (independent variable) dengan variabel terikat (dependent variable).

Berdasarkan jenis data, penelitian ini termasuk ke dalam penelitian kuantitatif. Menurut Sugiyono (2007), penelitian kuantitatif merupakan penelitian yang datanya dinyatakan dalam bentuk angka, atau penelitian yang dilakukan dengan cara mengumpulkan data yang ada hubungannya dengan judul penelitian dan menganalisisnya dengan data yang diperoleh.

\section{0 | Jurnal Buana Akuntansi}




\section{Buana Akuntansi}

Populasi yang digunakan dalam penelitian ini adalah seluruh perusahaan manufaktur yang terdaftar di Bursa Efek Indonesia (BEI) periode 2015-2017, yaitu sebanyak 154 perusahaan. Teknik sampling yang digunakan dalam penelitian ini adalah nonprobability sampling yaitu purposive sampling. Purposive sampling yaitu teknik penentuan sampel dengan pertimbangan/kriteria tertentu (Sugiyono, 2007:68).

\section{Analisis dan Pembahasan}

Berdasarkan uji statistik deskriptif, dapat disimpulkan bahwa jumlah data yang digunakan dalam penelitian ini sebanyak 93 data. Rata-rata (mean) ukuran perusahaan sebesar 3,1017 dengan standar deviasi sebesar 0,64067 dan variance sebesar 0,410. Rata-rata (mean) risiko perusahaan sebesar 1,4922 dengan standar deviasi sebesar 4,47244. Rata-rata (mean) profitabilitas sebesar 0,0863 dengan standar deviasi sebesar 0,07775. Rata-rata (mean) perataan laba sebesar 0,5332 dengan standar deviasi sebesar 0,29560.

Berdasarkan hasil uji One-Sample kolmogorov-smirnov test bahwa variabel risiko perusahaan dan profitabilitas tidak berdistribusi normal, sedangkan variabel ukuran perusahaan dan perataan laba berdistribusi normal. Data yang tidak berdistribusi normal dapat ditransformasi agar menjadi normal (Ghozali, 2006:33). Salah satu cara agar data dapat berdistribusi normal adalah dengan melakukan transformasi data dengan cara logaritma natural (Ln) kepada masing-masing variabel. Setelah dilakukan Ln, data ukuran perusahaan, risiko perusahaan, profitabilitas, dan perataan laba memperlihatkan hasil berdistribusi normal.

\subsection{Pengaruh Ukuran Perusahaan terhadap Praktik Perataan Laba}

Nilai koefisien determinasi ukuran perusahaan sebesar 0,08\% artinya kontribusi ukuran perusahaan dalam menjelaskan variasi praktik perataan laba (income smoothing) sangat kecil hanya sebesar $0,08 \%$. Berdasarkan hasil analisis tersebut dapat disimpulkan bahwa ukuran perusahaan tidak berpengaruh terhadap praktik perataan laba (income smoothing). Hal ini menunjukkan bahwa semakin besarnya ukuran perusahaan belum tentu menimbulkan keinginan manajemen untuk melakukan praktik perataan laba. Hal ini konsisten dengan penelitian yang dilakukan oleh Antariksa dan Eka (2005), Dhamar (2010), dan Wahidatul Husnaini dan Rosyida (2006) yang menunjukkan bahwa ukuran perusahaan tidak memiliki pengaruh yang signifikan terhadap praktik perataan laba (income smoothing).

\subsection{Pengaruh Risiko Perusahaan terhadap Praktik Perataan Laba}

Nilai koefisien determinasi risiko perusahaan (yang diwakili oleh DER) sebesar 0,6\% artinya bahwa kontribusi risiko perusahan dalam menjelaskan variasi praktik perataan laba

\section{1 | Jurnal Buana Akuntansi}




\section{Buana Akuntansi}

(income smoothing) sebesar 0,6\% sedangkan sisanya sebesar $99,4 \%$ dijelaskan oleh faktor lain. Berdasarkan hasil analisis tersebut, maka dapat disimpulkan bahwa risiko perusahaan tidak mempunyai pengaruh yang signifikan terhadap praktik perataan laba (income smoothing). Hasil penelitian ini tidak konsisten dengan penelitian yang dilakukan oleh Antariksa dan Eka (2005) dan Dhamar (2010) yang menyatakan bahwa risiko perusahan memiliki pengaruh yang signifikan terhadap praktik perataan laba (income smoothing). Penelitian ini menunjukkan bahwa perusahaan yang memiliki tingkat risiko perusahaan yang tinggi belum tentu melakukan praktik perataan laba. Hal ini sesuai dengan teori yang dikemukakan oleh Bitner dan Dolan (1996) dalam Dhamar (2010) bahwa perusahaan dengan tingkat risiko keuangan yang tinggi akan menyebabkan manajemen cenderung untuk tidak melakukan praktik perataan laba (income smoothing) karena perusahaan tidak ingin berbuat sesuatu yang membahayakan dalam jangka panjang. Oleh karena itu, perusahaan dengan tingkat risiko yang rendah mungkin cenderung untuk melakukan praktik perataan laba (income smoothing).

\subsection{Pengaruh Profitabilitas terhadap Praktik Perataan Laba}

Nilai koefisien determinasi profitabilitas (yang diwakili oleh ROA) sebesar $24,50 \%$ artinya bahwa kontribusi profitabilitas dalam menjelaskan variasi praktik perataan laba (income smoothing) sebesar $24,50 \%$. Dapat disimpulkan bahwa profitabilitas memiliki kontribusi yang besar terhadap terhadap praktik perataan laba (income smoothing), hal ini dapat dilihat dari hasil koefisien determinasi $R x_{3} y=0,245$. Nilai tersebut menunjukkan bahwa kontribusi profitabilitas dalam menjelaskan variasi praktik perataan laba (income smoothing) sebesar $24,50 \%$, sedangkan sisanya sebesar $75,5 \%$ dijelaskan oleh faktor lain. Hasil penelitian ini konsisten dengan penelitian yang dilakukan oleh Fongwati (2006), Etty dan Tobia (2006), dan Igan Budiasih (2009) menjelaskan variabel profitabilitas sebagai variabel dependen. Hasil yang diperoleh dari masing-masing penelitian yang dilakukan menyatakan bahwa profitabilitas memiliki pengaruh yang signifikan terhadap praktik perataan laba (income smoothing). Hal ini sesuai dengan teori yang dikemukakan oleh Carlson dan Bathala (1996) dalam Dhamar (2010) menyimpulkan bahwa tingkat profitabilitas perusahaan merupakan faktor yang mempengaruhi tindakan pengelolaan laba yang dilakukan oleh manajemen, karena sesuai dengan hipotesis biaya politik bahwa tingkat profitabilitas yang semakin tinggi akan mengakibatkan tingginya harapan dari regulator dan masyarakat kepada perusahaan tersebut untuk memberikan kompensasi kepada mereka berupa pembayaran pajak kepada regulator dan program sosial kepada masyarakat. Maka dapat disimpulkan bahwa profitabilitas memiliki pengaruh yang signifikan terhadap praktik perataan laba (income smoothing), karena sebagian besar investor

\section{2 | Jurnal Buana Akuntansi}




\section{Buana Akuntansi}

dan kreditor menggunakan profitabilitas sebagai tolok ukur dalam menilai seberapa efektif perusahaan mengelola sumber-sumber yang dimilikinya dan juga merupakan bahan pertimbangan utama bagi investor dan kreditor dalam mengambil keputusan baik dalam menginvestasikan dana maupun dalam meminjamkan dana pada suatu perusahaan (Zuhroh, 1996 dalam Antariksa dan Eka , 2005).

\subsection{Pengaruh Ukuran Perusahaan, Risiko Perusahaan dan Profitabilitas (secara simultan) terhadap Praktik Perataan Laba}

Nilai koefisien determinasi ukuran perusahaan, risiko perusahaan, dan profitabilitas sebesar $25,60 \%$ artinya bahwa kontribusi ukuran perusahaan, risiko perusahaan, dan profitabilitas secara bersama-sama dalam menjelaskan variasi praktik perataan laba (income smoothing) sebesar $25,60 \%$. Ukuran perusahaan, risiko perusahaan, dan profitabilitas memiliki kontribusi yang besar terhadap praktik perataan laba (income smoothing), hal ini dapat dilihat dari hasil koefisien determinasi $R x_{1}, x_{2}, x_{3} y=0,256$. Nilai tersebut menunjukkan bahwa kontribusi ukuran perusahaan, risiko perusahaan, dan profitabilitas dalam menjelaskan variasi praktik perataan laba (income smoothing) sebesar $25,60 \%$, sedangkan sisanya sebesar $74,4 \%$ dijelaskan oleh faktor lain. Secara bersama-sama (simultan) ukuran perusahaan, risiko perusahaan, dan profitabilitas memiliki pengaruh yang signifikan terhadap praktik perataan laba (income smoothing). Hasil penelitian ini konsisten dengan penelitian yang dilakukan oleh Wahidatul Husnaini dan Rosyida (2006) yang menyatakan bahwa terdapat pengaruh yang signifikan antara ukuran perusahaan dan profitabilitas terhadap praktik perataan laba (income smoothing) secara bersama-sama (simultan). Berdasarkan hasil analisis regresi berganda dan koefisien determinasi tersebut, maka dapat disimpulkan bahwa ukuran perusahaan, risiko perusahaan, dan profitabilitas secara simultan memiliki pengaruh yang signifikan terhadap praktik perataan laba (income smoothing).

Hasil penelitian ini menunjukkan bahwa dari ketiga variabel hanya profitabilitas yang berpengaruh terhadap praktik perataan laba (income smoothing) dan ukuran perusahaan, risiko perusahaan, dan profitabilitas secara bersama-sama (simultan) memiliki pengaruh yang signifikan terhadap praktik perataan laba (income smoothing).

\section{3 | Jurnal Buana Akuntansi}




\section{Buana Akuntansi}

\section{Kesimpulan, Keterbatasan, dan Saran}

\subsection{Kesimpulan}

Berdasarkan hasil analisis yang telah dikemukakan pada bab 4 mengenai ukuran perusahaan, risiko perusahaan, dan profitabilitas terhadap praktik perataan laba pada perusahaan manufaktur yang terdaftar di Bursa Efek Indonesia (BEI) periode 2015-2017, maka dapat ditarik kesimpulan sebagai berikut:

1. Ukuran perusahaan tidak memiliki pengaruh signifikan terhadap praktik perataan laba (income smoothing). Hasil ini tidak konsisten dengan penelitian yang dilakukan oleh Fongwati (2006) dan Igan Bidiasih (2009) yang menunjukkan bahwa salah satu praktik perataan laba (income smoothing) dipengaruhi oleh faktor ukuran perusahaan. Tetapi hasil ini konsisten dengan penelitian yang dilakukan oleh Dhamar (2010), Antariksa dan Eka (2005), Muhammad Yusuf dan Soraya (2004), dan Wahidatul Husnaini dan Rosyida (2006) yang menunjukkan bahwa ukuran perusahaan bukan merupakan faktor pendorong terjadinya praktik perataan laba (income smoothing).

2. Risiko perusahaan yang diwakili oleh Debt to Equity Ratio (DER) tidak memiliki pengaruh signifikan terhadap praktik perataan laba (income smoothing). Hasil ini tidak sesuai dengan penelitian yang dilakukan oleh Antariksa dan Eka (2005) dan Dhamar (2010) yang menunjukkan bahwa risiko perusahaan bukan merupakan faktor pendorong terjadinya praktik perataan laba (income smoothing).

3. Profitabilitas yang diwakili oleh Return on Total Assets (ROA) memiliki pengaruh yang signifikan terhadap praktik perataan laba (income smoothing). Hasil ini tidak konsisten terhadap hasil penelitian yang dilakukan oleh Dhamar (2010), Muhammad Yusuf dan Soraya (2004), dan Wahidatul Husnaini dan Rosyida (2006) yang menyatakan bahwa profitabilitas bukan merupakan faktor pendorong terjadinya praktik perataan laba (income smoothing). Tetapi hasil ini konsisten dengan penelitian yang dilakukan oleh Fongwati (2006), Igan Budiasih (2009), Etty dan Tobia (2006), dan Antariksa dan Eka (2005) yang menunjukkan bahwa profitabilitas merupakan faktor pendorong terjadinya praktik perataan laba (income smoothing).

4. Ukuran perusahaan, risiko perusahaan (DER), dan profitabilitas (ROA) secara bersamasama (simultan) memiliki pengaruh yang signifikan terhadap praktik perataan laba (income smoothing). Hasil ini konsisten dengan hasil penelitian yang dilakukan oleh Igan Budiasih (2009) yang menunjukkan bahwa variabel ukuran perusahaan dan profitabilitas secara

\section{4 | Jurnal Buana Akuntansi}




\section{Buana Akuntansi}

bersama-sama memiliki pengaruh signifikan terhadap terjadinya praktik perataan laba (income smoothing).

\subsection{Keterbasan}

Penulis menyadari sepenuhnya, bahwa masih banyak terdapat keterbatasan dalam penelitian ini antara lain :

1. Rentang waktu yang dilakukan masih relatif singkat yaitu selama tiga tahun dari tahun 2007-2009.

2. Penelitian ini hanya meneliti perusahaan manufaktur saja, sedangkan masih banyak perusahaan-perusahaan lain yang terdaftar di BEI.

3. Variabel yang digunakan hanya ukuran perusahaan, risiko perusahaan, dan profitabilitas saja, sedangkan masih banyak faktor-faktor lain yang diduga mempengaruhi praktik perataan laba (income smoothing).

Dalam menentukan perusahaan perata laba dan bukan perata laba, penulis menggunakan model indeks eckel.

\subsection{Saran}

Untuk penelitian selanjutnya, diharapkan untuk memperhatikan beberapa hal sebagai berikut:

1. Rentang waktu yang digunakan untuk penelitian selanjutnya lebih lama, sehingga hasil yang diperoleh dapat lebih akurat.

2. Penelitian selanjutnya sebaiknya tidak hanya menggunakan perusahaan manufaktur, penelitian dapat dilakukan pada sektor industri, perbankan, dan perusahaan-perusahaan gopublic lainnya.

3. Variabel yang digunakan dalam penelitian selanjutnya dapat ditambah seperti Net Profit Margin, besaran perusahan, pendanaan hutang dan faktor-faktor lain yang diduga mempengaruhi praktik perataan laba (income smoothing).

4. Dalam menentukan perusahaan perata laba dan bukan perata laba penelitian selanjutnya diharapkan menggunakan model lain selain indeks eckel, yaitu seperti discretionary accrual dengan modified jones. 


\section{Buana Akuntansi}

\section{Daftar Pustaka}

Aji, Dhamar Yudho, dan Aria Farah Mita, "Pengaruh Profitabilitas, Risiko Keuangan, Nilai Perusahaan, Dan Struktur Kepemilikan Terhadap Praktek Perataan Laba: Studi Empiris Perusahaan Manufaktur Yang Terdaftar Di BEI", SNA XIII Purwokerto, 2010.

Beidlman, C., "Income Smoothing: The Role of Management", The Accounting Review, 1973, 653-668.

Belkaoui, Ahmed R. 1993. Accounting Theory $3^{\text {rd }}$ Edition. The University Press: Cambridge.

Budileksamana, Antariksa, dan Andriani, Eka. "Faktor-Faktor yang Mempengaruhi Praktik Perataan Laba pada Perusahaan-Perusahaan Di Bursa Efek Jakarta", Jurnal Akuntansi dan Investasi, Vol. 6. No. 1, 2005, hal 187-205.

Bitner, Larry N. \& Robert C. Dolan, "Assessing the Relationship Between Smoothing ant the Value of The Firm", OJBE, 35 (1), 1996, hal. 16-35.

Budhijono, Fongwati, "Evaluasi Perataan Laba Pada Industri Manufaktur Dan Lembaga Keuangan Yang Terdaftar Di BEJ", Fakultas Ekonomi Universitas Kristen Satya Kencana, 2006.

Budiasih, Igan, "Faktor-faktor yang Mempengaruhi Perataan Laba". Jurnal Akuntansi dan Bisnis, Volume 1, Januari 2009.

Carlson, Steven J, dan Bathala, Chenchuramaiah T., "Ownership Differences and Firm's Income Smoothing Behavior", Journal of Business and Accounting, 24 (2), March 1997: 179-196.

Ghozali, Imam. 2006. Aplikasi Analisis Multivariate dengan Program SPSS (Edisi ke 4). Semarang: Badan Penerbit Universitas Diponegoro.

Husnaini, Wahidatul dan Astuti, B. Rosyida Dwi, "Analisis Faktor-Faktor yang Mempengaruhi Income Smoothing", Jurnal Riset Akuntansi Aksioma, 5 (2), 2006.

Jatiningrum, "Analisis Faktor-Faktor yang Berpengaruh terhadap Perataan Penghasilan Bersih/Laba pada Perusahaan yang Terdaftar di BEJ", Jurnal Bisnis dan Akuntansi, 2 (2), 2000.

Nasser, Etty M., dan Parulian, Tobia, "Pengaruh Faktor-Faktor Internal Perusahaan Terhadap Income Smoothing", Media Riset Akuntansi, Auditing, dan Informasi, 6(1), 2006.

Prabayanti, Ni Luh Putu Arik, dan Yasa, Gerianta Wirawan, "Perataan Laba (Income Smoothing) dan Analisis Faktor-Faktor yang Mempengaruhinya (Studi pada Perusahaan Manufaktur yang Terdaftar di Bursa)", Jurnal IImiah Akuntansi dan Bisnis, 6 (1), 2008.

Prasetio, Januar Eko, Wiryawan, A., dan Astuti, S., "Praktik Perataan Laba dan Kinerja Saham Perusahaan Publik di Indonesia", Jurnal Akuntansi dan Auditing, 6 (2), 2002, hal : 45-63.

Sugiyono. 2007. Metode Penelitian Akuntansi, Edisi 10. Bandung: CV Alfabeta.

Yusuf, Muhammad dan Soraya, "Faktor-Faktor Yang Mempengaruhi Praktik Perataan Laba Pada Perusahaan Asing dan Non Asing di Indonesia", Jurnal Akuntansi dan Auditing Indonesia, Vol. 8, No. 1, 2004. 